\title{
Keanekaragaman Nematoda Tanah di Blok Pemanfaatan Hutan Pendidikan Konservasi Terpadu Taman Hutan Raya Wan Abdul Rachman
}

\author{
Diversity of Soil Nematode in Utilization Block \\ Integrated Educational Conservation Forest, Wan Abdul Rachman Great \\ Forest Park \\ Oleh: \\ Yoshua Gdemakarti $^{1}$, Bainah Sari Dewi ${ }^{1}$, I Gede Swibawa ${ }^{2}$ \\ ${ }^{1}$ Jurusan Kehutanan, Fakultas Pertanian, Universitas Lampung \\ ${ }^{2}$ Jurusan Proteksi Tanaman, Fakultas Pertanian, Universitas Lampung \\ Jl. Soemantri Brojonegoro No. 1, Gedong Meneng, Bandar Lampung 35145, Lampung, Indonesia \\ *Email: gdemakarti@gmail.com
}

\begin{abstract}
ABSTRAK
Perubahan lahan hutan menjadi lahan agroforestri mempengaruhi kondisi tutupan lahan dan menurunkan kandungan bahan organik tanah. Nematoda merupakan salah satu biota tanah yang dapat dijadikan sebagai indikator perubahan lingkungan tanah. Penelitian yang dilaksanakan Bulan April - Mei 2018 bertujuan untuk mengetahui komunitas dan keanekaragaman nematoda di Blok Pemanfaatan Hutan Pendidikan Konservasi Terpadu Taman Hutan Raya Wan Abdul Rachman. Sampel tanah diambil di arboretum satu, arboretum dua, arboretum tiga dan arboretum empat yang terletak di Hutan Pendidikan Konservasi Terpadu Taman Hutan Raya Wan Abdul Rachman. Pengamatan nematoda dilakukan di Laboratorium Ilmu Hama Tumbuhan, Fakultas Pertanian, Universitas Lampung. Nematoda diidentifikasi hingga tingkat genus berdasarkan ciri morfologinya. Analisis menggunakan indeks keanekaragaman, dominansi dan kesamaan genus antar arboretum. Hasil penelitian menemukan 30 genus nematoda yang terdiri dari 19 genus nematoda parasit tumbuhan, enam genus nematoda pemakan bakteri, tiga genus nematoda pemakan jamur dan dua genus nematoda predator. Genus nematoda yang dominan yaitu Criconomella, Helycotylenchulus dan Rotylenchulus. Kelimpahan seluruh nematoda berkisar $171-617$ individu/300 $\mathrm{cm}^{3}$ tanah. Keanekaragaman nematoda tergolong sedang dengan indeks Shannon-Wienner berkisar 2,47 - 2,80 dan Indeks Simpson berkisar 0,89-0,93. Indeks kesamaan genus tertinggi yaitu 0.81 terjadi antara arboretum tiga dengan arboretum empat dan terendah yaitu 0,54 yaitu antara arboretum dua dengan arboretum tiga.
\end{abstract}

Kata Kunci: komunitas nematoda, Hutan Pendidikan Konservasi Terpadu, Taman Hutan Raya Wan Abdul Rachman

\section{ABSTRACT}

Change of land forest in Wan Abdul Rachman Forest Park became agroforestry, affect of cover condition and decrease the content of soil matter. Nematode was one of the soils biotas that can be used as an indicator of change in the soil status. The aim of study is to know the community and diversity of nematodes on the Utilization Block, Integrated Educational Conservation Forest, Wan Abdul Rachman Great Forest Park. The research was conducted in April to May 2018. The soil samples were taken on arboretum one, arboretum two, arboretum three and 
arboretum four in Integrated Educational Conservation Forest, Wan Abdul Rachman Great Forest Park. Nematode observations were conducted in the Plant Pests Laboratory, Faculty of Agriculture, University of Lampung. Nematodes was identified to genus level based on morphological traits. The analysis used were including the index of diversity, dominance and similarities between genus arboretum. The results showed that there were 30 genus of nematode consists of 19 plant parasitic nematode genera, six nematoda bacterial-feeding, three nematode fungal-feeding and two predator nematodes. The dominant nematode genera were Criconomella, Helycotylenchulus and Rotylenchulus. The abundance of nematodes ranges from 171-617 individuals $300 \mathrm{~cm}^{3}$ soil. The diversity of soil nematodes based on the ShannonWienner index ranges from 2,47 - 2,80. The Shannon-Whienner Index criteria were classified as moderate. The Simpson Index ranges from 0,89-0,93. The highest similarity index genus in arboretum three and four with a value of 0,81 and the lowest in arboretum two and three which is 0,54 .

Key words: nematodes community, Integrated Educational Conservation Forest, Wan Abdul Rachman Great Forest Park

\section{PENDAHULUAN}

Hutan Pendidikan Konservasi Terpadu (HPKT) merupakan bagian dari Taman Hutan Raya (Tahura) Wan Abdul Rachman yang pengelolaannya bekerja sama dengan pihak Universitas Lampung untuk menunjang kegiatan penelitian dan pendidikan. Kondisi vegetasi di kawasan ini bervariasi yang terdiri dari vegetasi hutan primer maupun sekunder, semak belukar, kebun dan agroforestri (Dewi et al. 2017; UPTD Tahura WAR 2009, 2017). Luasan tutupan lahan di Tahura Wan Abdul Rachman pada tahun 2014 hanya 8.953 ha atau 40,2\% dari luas seluruh hutan (Handoko dan Darmawan 2015).

Perubahan fungsi lahan hutan menjadi lahan pertanian dapat mengubah jumlah masukan bahan organik tanah yang diproduksi oleh seresah permukaan (Sagita et al. 2017; Tolaka et al. 2013) dan mempengaruhi siklus unsur hara (Salim dan Budiadi 2014). Faktor ini dapat mempengaruhi populasi biota tanah karena bahan organik merupakan sumber energi utama untuk keberlangsungan hidupnya (Hilwan dan Handayani 2013; Qifli et al. 2017).

Data mengenai komunitas nematoda dapat digunakan untuk melihat kualitas tanah serta gambaran adanya perubahan lingkungan tanah karena populasi nematoda sangat cepat dalam merespon gangguan pada kondisi tanah (Carrascosa et al. 2014; Nielsen et al. 2014). Informasi tentang komunitas nematoda sangat diperlukan untuk mengetahui kualitas tanah (Godefroid et al. 2013). Data mengenai komunitas nematoda masih belum ada sehingga perlu dilakukan penelitian. Penelitian ini bertujuan untuk mengetahui komunitas nematoda di Blok Pemanfaatan, HPKT Tahura WAR.

\section{METODE PENELITIAN}

\section{Tempat dan Waktu Penelitian}

Penelitian ini dilaksanakan pada Bulan April - Mei 2018. Pengambilan sampel tanah dilakukan di Blok Pemanfaatan Hutan Pendidikan Konservasi Terpadu Taman Hutan Raya Wan Abdul Rachman Provinsi Lampung. Pengamatan nematoda dilakukan di Laboratorium Ilmu Hama Tumbuhan, Fakultas Pertanian, Universitas Lampung. Pengambilan sampel tanah dilakukan di empat arboretum permanen di HPKT Tahura WAR yaitu arboretum satu, arboretum dua, arboretum tiga, dan arboretum empat (Gambar 1). 


\section{Alat dan Objek Penelitian}

Bahan yang digunakan berupa sampel tanah, larutan Golden X (campuran aquades, formalin dan gliserin dengan komposisi 90:8:2 bagian), larutan gula dan air. Alat yang digunakan dalam pengambilan sampel tanah adalah tembilang, kantung plastik, sekop kecil, pisau dan ember. Tahap ekstraksi dan fiksasi nematoda menggunakan alat timbangan elektrik, ember, saringan $(1 \mathrm{~mm}, 38 \mu \mathrm{m}$, dan $53 \mu \mathrm{m})$, botol semprot, centrifuge, tabung centrifuge, stopwatch, gelas ukur, botol suspensi dan label. Sedangkan dalam pengamatan nematoda menggunakan alat mikroskop stereo binocular dan mikroskop compound, cawan petri, pengait nematoda, hand counter, beaker glass, kaca preparat, dan cover glass. Sedangkan alat untuk mengamati morfologi nematoda menggunakan buku identifikasi (Goodey 1963; Mai 1985; Siddiqi 1986).
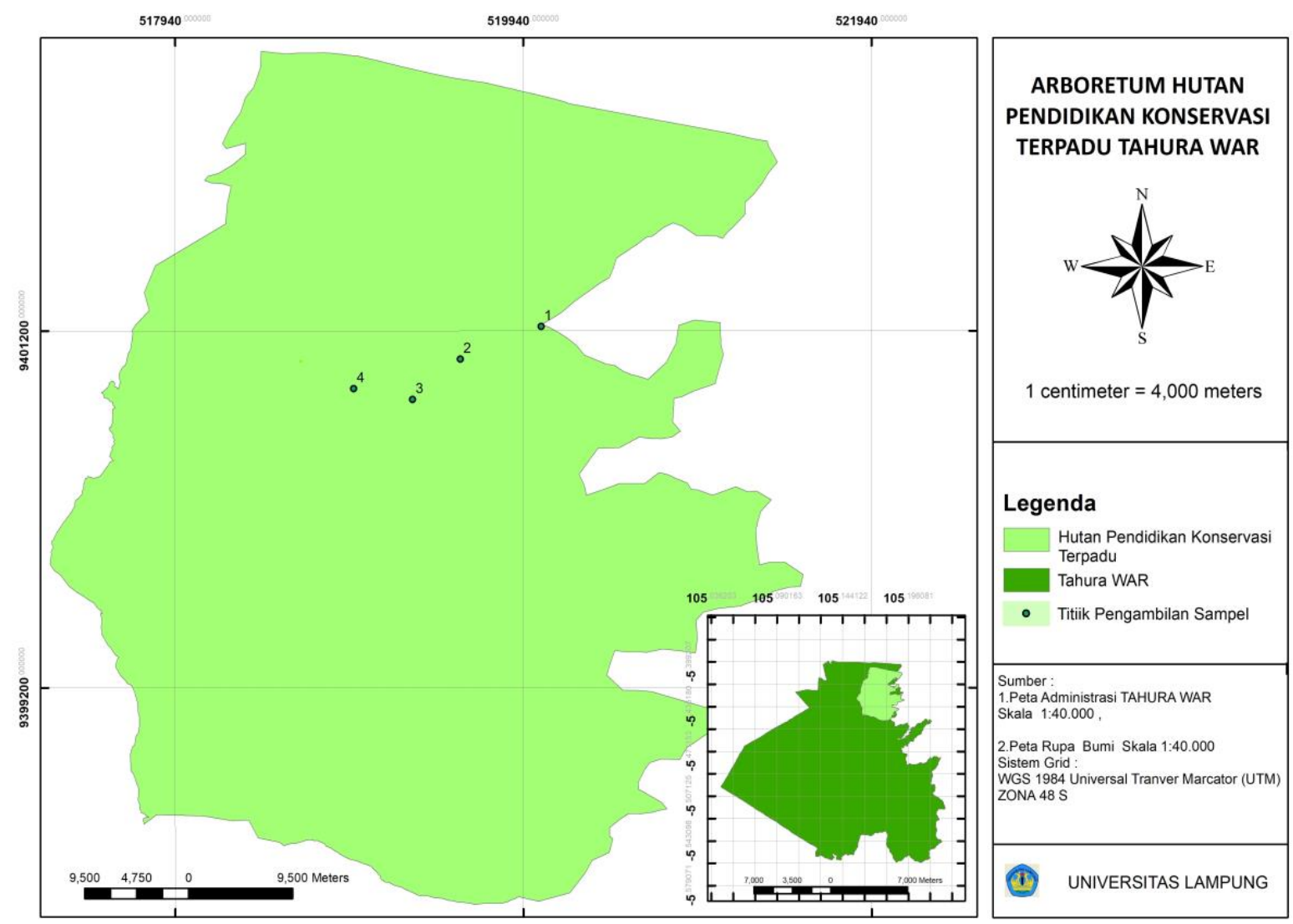

Gambar 1. Peta lokasi pengambilan sampel tanah di HPKT Tahura WAR dengan skala $1: 40.000$.

\section{Metode Pengambilan Data}

Pengambilan sampel tanah dilakukan di arboretum berukuran $20 \mathrm{~m}$ x $20 \mathrm{~m}$. Sampel tanah diambil dari 12 sub titik sampel yang dibagi ke dalam lingkaran besar dan lingkaran kecil. Pada lingkaran kecil terdapat empat titik sampel dengan jarak tiga meter dari titik pusat, sedangkan pada lingkaran besar terdapat delapan titik sampel dengan jarak lintasan sejauh tiga meter dari lingkaran kecil. Pada setiap sub titik diambil sampel tanah sebanyak $500 \mathrm{~g}$ dengan kedalaman $0-20 \mathrm{~cm}$. Semua sampel tanah yang diambil dari tiap-tiap titik sampel tersebut di campur rata dan diambil $500 \mathrm{~g}$ untuk diekstraksi di laboratorium. Posisi pengambilan titik sampel tanah diilustrasikan pada Gambar 2. 


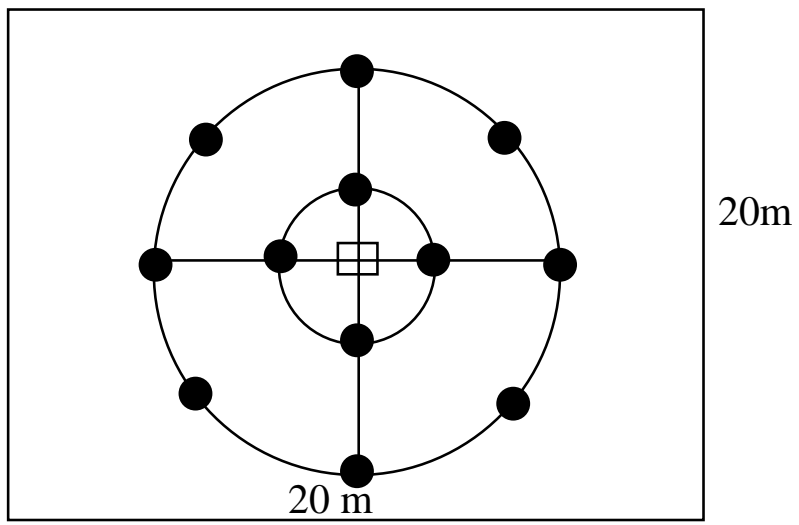

Gambar 2. Posisi sub-titik sampel pengambilan sampel tanah (Gafur dan Swibawa 2004).

Ekstraksi nematoda tanah menggunakan metode penyaringan bertingkat dan sentrifugasi menggunakan larutan gula. Sampel tanah yang telah dicampur rata diambil $300 \mathrm{cc}$ kemudian dibersihkan dan disaring dengan menggunakan saringan bertingkat berukuran lubang satu millimeter, $53 \mu \mathrm{m}$ dan $38 \mu \mathrm{m}$. Nematoda hasil ekstraksi dimatikan dengan memanaskan suspensi dengan suhu $60^{\circ}-70^{\circ} \mathrm{C}$. Nematoda difiksasi menggunakan larutan Golden $\mathrm{X}$ yaitu campuran formalin, gliserin, akuades dengan komposisi (8:2:90). Nematoda yang sudah difiksasi dihitung di bawah mikroskop stereo pada perbesaran 40x dengan bantuan hand counter.

Preparat permanen dibuat untuk keperluan identifikasi, satu preparet berisi 100 nematoda yang diambil secara acak dari nematode yang telah diinfiltarsi gliserin menggunakan metode Seinhorst. Nematoda diidentifikasi hingga tingkat genus berdasarkan ciri morfologinya kemudian dikelompokkan ke dalam kelompok makan nematoda yaitu nematoda parasit tumbuhan dan nematoda hidup bebas yang meliputi nematoda pemakan bakteri, nematoda pemakan jamur, nematoda predator, dan nematoda omnivora (Yeates et al. 1993).

\section{Analisis Data}

Data komunitas nematoda pada beberapa arboretum dalam penelitian ini diukur keanekaragamannya, nilai dominansi, dan nilai kesamaan genus antar arboretum.

1. Analisis Indeks keanekaragaman nematoda

Keanekaragaman nematoda diukur menurut indeks keanekaragaman Shannon-Wiener dan Indeks Simpson. Indeks keanerakaragaman Shannon-Wienner (Matsushita et al. 2015) (Persamaan 1 dan 2). Dimana H' merupakan Indeks keanekaragaman Shannon-Wiener; ni merupakan Jumlah individu jenis ke-I; dan N merupakan Jumlah individu seluruh jenis.

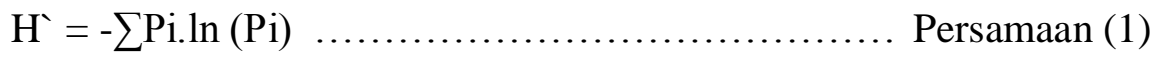

Dimana

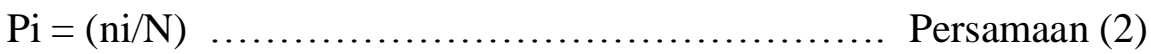

Kriteria nilai indeks keanekaragaman Shannon-Wiener:

$\mathrm{H}^{\prime}-1=$ keanekaragaman rendah

$1<\mathrm{H}^{\prime}<3 \quad=$ keanekaragaman sedang

$\mathrm{H}^{\prime}>3=$ keanekaraman tinggi 
Indeks keanekaragaman Simpson`s (Crotty et al. 2015; Putranto et al. 2017) dihitung dengan persamaan 3 dan 4. Dimana $\mathrm{H}_{2}$ merupakan Indeks Simpson; ni merupakan jumlah individu jenis ke-I; dan N merupakan Jumlah individu seluruh jenis.

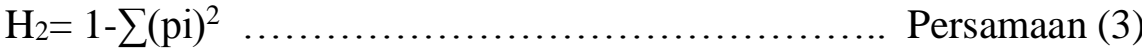

$$
\begin{aligned}
& \text { dimana }
\end{aligned}
$$

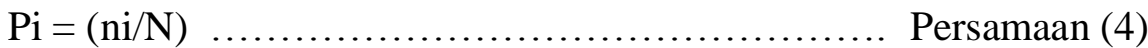

2. Nilai dominansi genus nematoda

Data komunitas nematoda di analisis untuk menentukan genus nematoda yang dominan menggunakan Prominence Value (PV) dengan Persamaan 5 (Norton 1978). Dimana PV merupakan prominence value; $K A$ merupakan kelimpahan absolut tiap genus; dan FA merupakan frekuensi absolut yaitu jumlah sampel yang mengandung genus/jumlah seluruh sampel $* 100$.

$$
\mathrm{PV}=\mathrm{KA} \times \sqrt{F A}
$$
Persamaan (5)

3. Analisis indeks kesamaaan genus antar arboretum

Indeks kesamaan (Sorensen Similarity) di hitung dengan menggunakan Persamaan 6 (Adelina et al. 2016; Norton 1978). Dimana C merupakan jumlah spesies yang sama yang terdapat pada dua lokasi; A merupakan jumlah spesies yang dijumpai pada lokasi 1; dan B merupakan jumlah spesies yang dijumpai pada lokasi 2 .

$$
\text { IS }=2 \mathrm{C} / \mathrm{A}+\mathrm{B}
$$
Persamaan (6)

Kriteria Indeks Kesamaan (Sorensen Similarity) yaitu:

$1-30 \%=$ Kategori rendah,

$31-60 \%=$ Kategori sedang,

$61-91 \%=$ Kategori tinggi,

$>91 \%=$ Kategori sangat tinggi

\section{HASIL DAN PEMBAHASAN}

\section{Komunitas Nematoda}

Komunitas nematoda yang ditemukan pada Blok Pemanfaatan yaitu 30 genus nematoda yang terdiri dari 19 nematoda parasit tumbuhan dan 11 nematoda hidup bebas. Nematoda hidup bebas terdiri dari enam nematoda pemakan bakteri, tiga genus nematoda pemakan jamur dan dua genus nematoda predator (Gambar 3). Jumlah genus nematoda yang merupakan kelompok makan parasit tumbuhan yang ditemukan lebih banyak (19) dibandingkan dengan jumlah genus nematoda hidup bebas (11). 


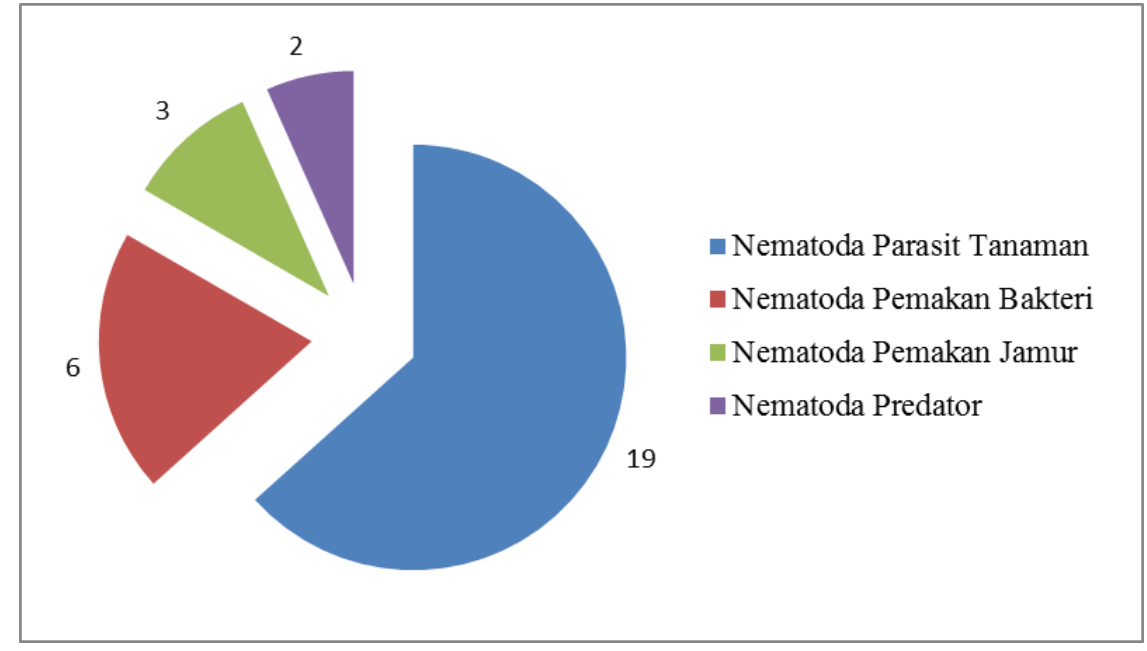

Gambar 3. Kelompok fungsi nematoda.

Banyaknya nematoda parasit tumbuhan yang ditemukan di daerah ini merupakan dampak dari pengelolaan lahan agroforestri oleh masyarakat (Godefroid et al. 2017). Menurut Landi et al. (2018), pergantian jenis tanaman juga berpengaruh pada struktur komunitas nematoda pada suatu daerah, hal ini sesuai dengan penelitian Franco-Navarro dan GodinezVidal (2017) yang menyebutkan bahwa nematoda parasit tumbuhan lebih dominan pada lahan agroforestri. Kondisi vegetasi di Blok Pemanfaatan HPKT Tahura WAR pada arboretum satu, arboretum dua, arboretum tiga dan arboretum empat dideskripsikan pada Tabel 1.

Tabel 1. Jenis-jenis pohon yang terdapat pada arboretum.

\begin{tabular}{|c|c|c|c|c|c|c|}
\hline \multirow{2}{*}{ No. } & \multirow{2}{*}{ Nama Umum } & \multirow{2}{*}{ Nama Ilmiah } & \multicolumn{4}{|c|}{ Jumlah Pohon pada Arboretum (\%) } \\
\hline & & & 1 & 2 & 3 & 4 \\
\hline 1 & Sawo Manila & Manilkara zapota & 7,1 & 0.0 & 0,0 & 0,0 \\
\hline 2 & Karet & Hevea brasiliensis & 14,3 & 0.0 & 0,0 & 23,5 \\
\hline 3 & Kelapa & Cocos nucifera & 28,6 & 0.0 & 0,0 & 0,0 \\
\hline 4 & Pinang & Areca catechu & 21,4 & 0.0 & 0,0 & 0,0 \\
\hline 5 & Jambu Batu & Psidium guajava & 7,1 & 0.0 & 0,0 & 0,0 \\
\hline 6 & Durian & Durio zibethinus & 14,3 & 57,1 & 36,4 & 47,1 \\
\hline 7 & Kesambi & Schleichera oleosa & 7,1 & 0,0 & 0,0 & 0,0 \\
\hline 8 & Petai & Parkia speciosa & 0,0 & 28,6 & 0,0 & 0,0 \\
\hline 9 & Tangkil & Gnetum gnemon & 0,0 & 7,1 & 0,0 & 0,0 \\
\hline 10 & Nangka & Artocarpus heterophyllus & 0,0 & 7,1 & 9,1 & 0,0 \\
\hline 11 & Kemiri & Aleurites moluccanus & 0,0 & 0,0 & 9,1 & 0,0 \\
\hline 12 & Alpukat & Persea Americana & 0,0 & 0,0 & 36,4 & 5,9 \\
\hline 13 & Randu & Ceiba pentandra & 0,0 & 0,0 & 9,1 & 0,0 \\
\hline 14 & Sonokeling & Dalbergia latifolia & 0,0 & 0,0 & 0,0 & 17,6 \\
\hline 15 & Kayu Manis & Cinnamomum verum & 0,0 & 00 & 0,0 & 5,9 \\
\hline \multicolumn{3}{|c|}{ Jumlah Pohon } & 14 & 14 & 11 & 17 \\
\hline \multicolumn{3}{|c|}{ Jumlah Jenis Pohon } & 7 & 4 & 5 & 5 \\
\hline
\end{tabular}

Sumber: Dewi et al. (2017). 
Hasil analisis Prominence Value menunjukkan bahwa beberapa genus nematoda yang dominan yang ditemukan di lokasi penelitian. Nilai Prominence Value beberapa genus nematoda di lokasi penelitian disajikan pada Tabel 2.

Tabel 2. Nilai Prominance Value (PV) genus beberapa kelompok fungsi nematoda.

\begin{tabular}{|c|c|c|}
\hline No. & Genus & Prominence Value \\
\hline \multicolumn{3}{|c|}{ A. Parasit Tumbuhan } \\
\hline 1 & Acontylus & 2,46 \\
\hline 2 & Criconema & 233,77 \\
\hline 3 & Crinonomella & 226,47 \\
\hline 4 & Gracilacus & 171,38 \\
\hline 5 & Helycotylenchus & 298,82 \\
\hline 6 & Meloidogyne & 70,42 \\
\hline 7 & Nothanguina & 3,38 \\
\hline 8 & Paratylenchus & 308,3 \\
\hline 9 & Pratylenchus & 114,33 \\
\hline 1 & Radopholus & 10,17 \\
\hline 1 & Rotylenchulus & 322,85 \\
\hline 1 & Rotylenchus & 40,32 \\
\hline 1 & Telotylenchus & 11,95 \\
\hline 1 & Tetylenchus & 101,45 \\
\hline 1 & Tylenchorhyncus & 72,37 \\
\hline 16 & Tylenchulus & 205,12 \\
\hline 17 & Tylenchus & 110.77 \\
\hline 18 & Tylodorus & 3,52 \\
\hline 19 & Xiphinema & 72,70 \\
\hline \multicolumn{3}{|c|}{ B. Pemakan Bakteri } \\
\hline 20 & Cryptonchus & 1,76 \\
\hline 2 & Diplocasterinae & 2,46 \\
\hline 22 & Pelodera & 4,92 \\
\hline 23 & Rabditida & 2,46 \\
\hline 2 & Rhabditis & 74,51 \\
\hline 2 & Xylorhabditis & 1,76 \\
\hline \multicolumn{3}{|c|}{ C. Pemakan Jamur } \\
\hline 26 & Aphelenchoides & 23,49 \\
\hline 2 & Aphelenchus & 179,10 \\
\hline $2 \xi$ & Ditylenchus & 164,67 \\
\hline \multicolumn{3}{|c|}{ D. Predator } \\
\hline 29 & Mononchus & 2,46 \\
\hline 30 & Iotonchus & 2,46 \\
\hline
\end{tabular}

Semakin besar nilai $P V$ pada suatu genus menunjukkan bahwa semakin dominan genus tersebut di suatu daerah. Berdasarkan Tabel 2, nilai Prominence Value yang tertinggi yaitu Paratylenchus $(308,3)$, Helycotylenchulus $(298,82)$ dan Rotylenchulus $(P V=322,85)$ yang merupakan nematoda parasit tanaman. Secara umum nematoda parasit tanaman pada lokasi penelitian ini banyak ditemukan pada tanaman perkebunan seperti tanaman kakao, kopi dan lada. Nematoda parasit tumbuhan dapat mengganggu proses fotosintesis dan transpirasi tanaman serta dapat menyebabkan tanaman lebih mudah terserang patogen sehingga mengakibatkan pertumbuhan tanaman terhambat. Serangan nematoda ini merugikan bagi tanaman karena dapat mengurangi kuantitas dan kualitas hasil tanaman sehingga dapat 
mengurangi pendapatan dari masyarakat (Mustika 2005). Dominasi dari nematoda parasit tumbuhan ini dipengaruhi oleh komposisi vegetasi yang didominasi oleh tanaman perkebunan seperti kakao dan pengelolaan lahan oleh masyarakat.

\section{Kelimpahan Nematoda}

Kelimpahan seluruh nematoda disajikan pada Gambar 4. Pada gambar tersebut tampak bahwa total seluruh individu nematoda tanah yang ditemukan bervariasi antara $171-617$ individu/300 $\mathrm{cm}^{3}$ tanah. Total kelimpahan nematoda pada penelitian ini lebih rendah dibandingkan dengan kelimpahan nematoda di hutan mahoni yang dilaporkan (Sagita et al. 2017) yaitu sebanyak 910 individu/300 $\mathrm{cm}^{3}$ tanah. Rendahnya kelimpahan nematoda di agroforestri karena sistem penggunaan lahan ini memiliki keadaan yang hampir sama dengan hutan yaitu dengan keragaman vegetasinya tinggi (Swibawa et al. 2009). Faktor yang mempengaruhi kelimpahan nematoda adalah struktur vegetasi, ketersediaan hara dan kandungan bahan organik tanah Grafik kelimpahan genus nematoda disajikan pada Gambar 4.

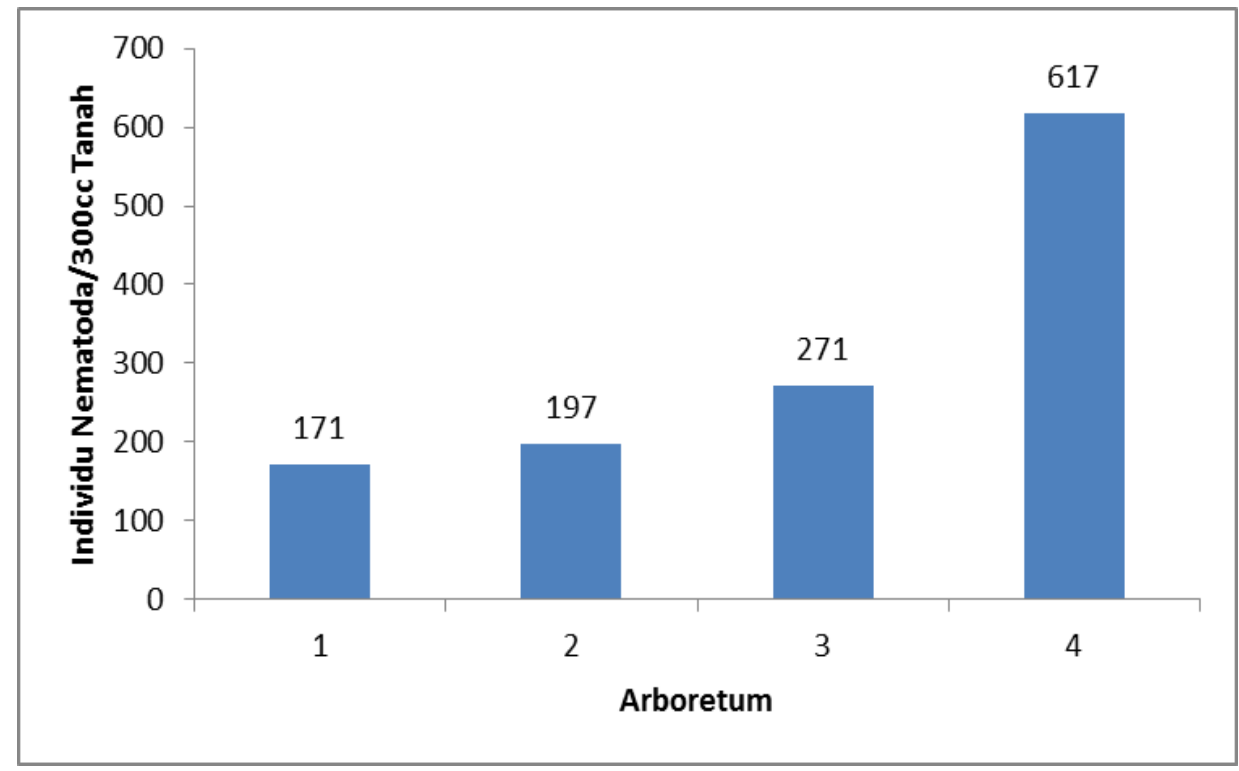

Gambar 4. Kelimpahan seluruh individu nematodapada empat arboretum.

\section{Keragaman Nematoda}

Keragaman nematoda yang terdapat di lokasi penelitian dapat dilihat pada Gambar 5. Indeks Shannon-Wiener tertinggi dijumpai pada arboretum dua yaitu 2,80 dan yang terendah dijumpai di arboretum tiga yaitu 2,47. Indeks ini menunjukkan bahwa keragaman nematoda di Blok Pemanfaatan termasuk sedang. Indeks keragaman Simpson's tertinggi dijumpai di arboretum dua yaitu 0,93 dan terendah pada arboretum satu yaitu 0,89. Berdasarkan hasil perhitungan, nilai indeks Simpson's termasuk tinggi (Putranto et al. 2017). Hal ini menunjukkan bahwa keragaman nematoda yang terdapat di lokasi penelitian mengindikasikan terdapat genus nematoda yang dominan. Hal ini ditunjukkan oleh adanya nematoda yang mendominasi dalam komunitas yaitu Rotylenchulus di blok pemanfaatan dengan nilai $P V=$ 322,85. Nilai keanekaragaman nematoda yang dihitung menggunakan indeks shannon-wiener pada penelitian ini lebih tinggi daripada penggunaan lahan monokultur yang dilaporkan oleh Franco-Navarro dan Godinez-Vidal (2017) yaitu sebesar 2,24. Hal ini membuktikan bahwa keanekaragaman nematoda peka terhadap gangguan pada tanah. Faktor yang mempengaruhi keanekaragaman nematoda adalah perbedaan jenis dan kerapatan tutupan tanah serta pengelolaan sistem agroforestri. Sistem agroforestri dapat merubah bahan organik tanah sehingga dapat merubah keanekaragaman organisme didalam tanah, termasuk nematoda 
Jaffuel et al. (2016). Semakin tinggi keragaman vegetasi maka semakin besar pula tingkat keragaman suatu komunitas nematoda (Swibawa et al. 2009).

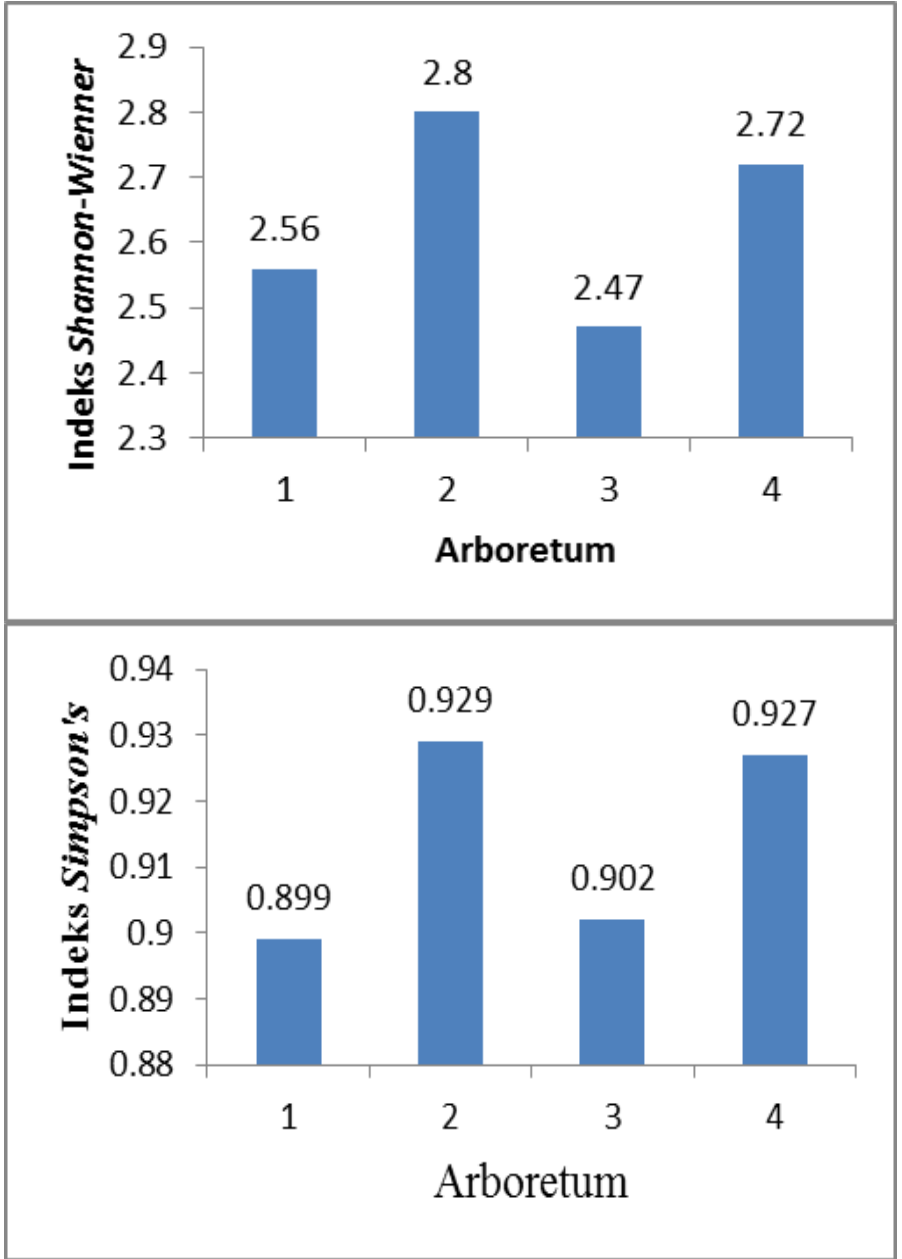

Gambar 5. Indeks Shannon-Wiener dan Indeks Simpson's nematoda.

\section{Kesamaan Genus nematoda antar Arboretum}

Tingkat kesamaan genus nematoda antar arboretum dapat dilihat pada Tabel 3. Nilai indeks kesamaan genus yang paling tinggi yaitu antara arboretum tiga dengan arboretum empat yaitu 0,81 yang termasuk dalam kategori tinggi. Tingkat kesamaan genus yang paling rendah yaitu antara arboretum dua dengan dan arboretum tiga yaitu 0,54 yang termasuk ke dalam kategori sedang (Adelina et al. 2016; Norton 1978). Jumlah ini masih lebih kecil dibandingkan dengan penelitian Cardoso et al. (2017) yang menyebutkan bahwa tingkat kesamaan genus nematoda antar plot di Brazil pada hutan tropis mencapai 0,95. Rendahnya indeks kesamaan genus antar arboretum pada penelitian ini dikarenakan adanya nematoda yang mendominasi di setiap arboretum.

Tabel 3. Nilai indeks Sorensen Similarity genus nematoda antar arboretum.

\begin{tabular}{ccccc}
\hline Arboretum & 1 & 2 & 3 & 4 \\
\hline 1 & 1 & & & \\
2 & 0,66 & 1 & & \\
3 & 0,60 & 0,54 & 1 & 1 \\
4 & 0,74 & 0,66 & 0,81 & \\
\hline
\end{tabular}




\section{SIMPULAN}

Komunitas nematoda yang ditemukan di Taman Hutan Raya Wan Abdul Rachman yaitu 30 genus yang terdiri dari 19 genus nematoda parasit tumbuhan, enam genus nematoda pemakan bakteri, tiga genus nematoda pemakan jamur dan dua genus nematoda predator. Kelimpahan seluruh individu nematoda mencapai 314 individu/ $300 \mathrm{~cm}^{3}$ tanah. Keanekaragaman komunitas nematoda di Taman Hutan Raya Wan Abdul Rachman yaitu tergolong sedang dengan indeks Shannon-Wienner berkisar 2,47 - 2,80 dan Indeks Simpson's berkisar $0,89-0,93$.

\section{DAFTAR PUSTAKA}

Adelina, M., Harianto, S. P., and Nurcahyani, N. 2016. Keanekaragaman Jenis Burung di Hutan Rakyat Pekon Kelungu Kecamatan Kota Agung Kabupaten Tanggamus. Jurnal Sylva Lestari 4(2): 51-60. DOI: 10.23960/js12451-60

Cardoso, M. S. O., Pedrosa, E. M. R., Ferris, H., Rolim, M. M., and Oliveira, L. S. C. 2017. Nematode Fauna of Tropical Rainforest in Brazil: A Descriptive and Seasonal Approach. Journal of Nematology Journal of Nematology 48(2): 116-125.

Carrascosa, M., Sánchez-Moreno, S., and Alonso-Prados, J. L. 2014. Relationships between nematode diversity, plant biomass, nutrient cycling and soil suppressiveness in fumigated soils. European Journal of Soil Biology 62: 49-59. DOI: 10.1016/j.ejsobi.2014.02.009

Crotty, F. V., Fychan, R., Scullion, J., Sanderson, R., and Marley, C. L. 2015. Assessing the impact of agricultural forage crops on soil biodiversity and abundance. Soil Biology and Biochemistry 91: 119-126. DOI: 10.1016/j.soilbio.2015.08.036

Dewi, B. S., Safe'i, R., Susilo, F. X., Bintoro, A., Swibawa, I. G., and Kaskoyo, H. 2017. Biodiversitas Flora dan Fauna di Arboretum Hutan Pendidikan Konservasi Terpadu Tahura Wan Abdul Rachman. Plantaxia, Jakarta.

Franco-Navarro, F., and Godinez-Vidal, D. 2017. Nematodos del suelo asociados a diferentes usos del suelo en la Reserva de la Biosfera Los Tuxtlas, Veracruz, México. Revista Mexicana de Biodiversidad 88(1): 136-145. DOI: 10.1016/j.rmb.2017.01.002

Gafur, A., and Swibawa, I. G. 2004. Methods in nematode and soil microbe research for belowground biodiversity assessment. in: Conservation and Sustainable Management of Belowground Biodiversity in Indonesia. Susilo, F.X.; Gafur, A; Utomo, M; Evizal, R; Murwani, S; Swibawa, I. G. ed. University of Lampung Press.

Godefroid, M., Delaville, L., Marie-Luce, S., and Quénéhervé, P. 2013. Spatial stability of a plant-feeding nematode community in relation to macro-scale soil properties. Soil Biology and Biochemistry 57: 173-181. DOI: 10.1016/j.soilbio.2012.06.019

Godefroid, M., Tixier, P., Chabrier, C., Djigal, D., and Quénéhervé, P. 2017. Associations of soil type and previous crop with plant-feeding nematode communities in plantain agrosystems. Applied Soil Ecology 113: 63-70. DOI: 10.1016/j.apsoil.2017.01.012

Goodey, J. B. 1963. Soil and Freshwater Nematodes. Mathuen and Co Ltd, London.

Handoko, and Darmawan, A. 2015. Perubahan tutupan hutan di Taman Hutan Raya Wan Abdul Rachman (Tahura WAR). Jurnal Sylva Lestari 3(2): 43-52. DOI: 10.23960/js12343-52

Hilwan, I., and Handayani, E. P. 2013. Keanekaragaman Mesofauna dan Makrofauna Tanah pada Areal Bekas Tambang Timah di Kabupaten Belitung, Provinsi Kepulauan BangkaBelitung. Jurnal Silvikultur Tropika Institut Pertanian Bogor (IPB) 4(1): 35-41.

Jaffuel, G., Mäder, P., Blanco-Perez, R., Chiriboga, X., Fliessbach, A., Turlings, T. C. J., and Campos-Herrera, R. 2016. Prevalence and activity of entomopathogenic nematodes and their antagonists in soils that are subject to different agricultural practices. Agriculture, 
Ecosystems and Environment 230: 329-340. DOI: 10.1016/j.agee.2016.06.009

Landi, S., Papini, R., d'Errico, G., Brandi, G., Rocchini, A., Roversi, P. F., Bazzoffi, P., and Mocali, S. 2018. Effect of different set-aside management systems on soil nematode community and soil fertility in North, Central and South Italy. Agriculture, Ecosystems \& Environment Elsevier 261: 251-260. DOI: 10.1016/J.AGEE.2018.01.003

Mai, W. F. 1985. Plant Parasitic Nematodes: Their Threat to Agriculture in J.N. Sasser and C.C.Carter (eds), An Edvanced Treeatise on Meloidogyne Volume I: Biology and Control. North Caroline State University Graphic, USA.

Matsushita, Y., Bao, Z., Kurose, D., Okada, H., Takemoto, S., Sawada, A., Nagase, H., Takano, M., Murakami, H., Koitabashi, M., Yoshida, S., Saito, M., Sano, T., and Tsushima, S. 2015. Community structure, diversity, and species dominance of bacteria, fungi, and nematodes from naturally and conventionally farmed soil: a case study on Japanese apple orchards. Organic Agriculture Springer Netherlands 5(1): 11-28. DOI: $10.1007 / \mathrm{s} 13165-015-0096-4$

Mustika, I. 2005. Konsepsi dan strategi pengendalian nematoda parasit tanaman perkebunan di Indonesia. Perspektif 4(1): 20.

Nielsen, U. N., Ayres, E., Wall, D. H., Li, G., Bardgett, R. D., Wu, T., and Garey, J. R. 2014. Global Scale Patterns Of Assemblage Structure Of Soil Nematodes In Relation To Climate And Ecosystem Properties. Global Ecology and Biogeography 23(9): 968-978.

Norton, D. C. 1978. Ecology of plant-parasitic nematodes. Ecology of plant-parasitic nematodes. John Wiley \& Sons, Inc., New York, USA.

Odum, E. P. (Eugene P. 1993. Dasar-dasar Ekologi (Terjemahan Tjahjono Samingan, Edisi Ketiga). Gadjah Mada Press, Yogyakarta.

Putranto, S., Zamani, N. P., Sanusi, H. S., Riani, E., and Fahrudin, D. A. 2017. Analisys and Mapping of Environmental Sensitivity Index in Banggai Regency and Banggai Islands Regency, Central Sulawesi. Jurnal Ilmu dan Teknologi Kelautan Tropis 9(1): 357-374.

Qifli, A. K., Hairiah, K., and Suprayogo, D. 2017. Studi Nitrifikasi Tanah dengan Penambahan Seresah Asal Hutan Alami dan Agroforestri Kopi. Jurnal Tanah dan Sumberdaya Lahan 1(2): 15-24.

Sagita, L., Siswanto, B., and Kurniatun, H. 2017. Studi Keragaman dan Kerapatan Nematoda pada Berbagai Sistem Penggunaan Lahan di Sub DAS Konto. Jurnal Tanah dan Sumberdaya Lahan 1(1): 51-60.

Salim, A. G., and Budiadi, B. 2014. Produksi dan Kandungan Hara Serasah pada Hutan Rakyat Nglanggeran, Gunung Kidul, D.I. Yogyakarta. Jurnal Penelitian Hutan Tanaman 12(2): 77-88. DOI: 10.20886/jpht.2014.11.2.77-88

Siddiqi, M. R. 1986. Tylenchida: parasites of plants and insects. Tylenchida: parasites of plants and insects. Commonwealth Agricultural Bureaux.

Swibawa, I. G., Evizal, R., Aini, F. K., Susilo, F. X., Hairiah, K., and Suprayogo, G. 2009. Penurunan Keragaman Pohon Dan Nematoda Akibat Alih Guna Hutan Menjadi Lahan Pertanian Memacu Munculnya Masalah Nematoda. in: Prosiding Konservasi Flora Indonesia dalam Mengatasi Dampak Pemanasan Global LIPI, Bali.

Tolaka, W., Wardah, and Rahmawati. 2013. Sifat Fisik Tanah Pada Hutan Primer, Agroforestri dan Kebun Kakao di Subdas Wea Saulopa Desa Leboni Kecamatan Pamona Puselemba Kabupaten Poso. Jurnal Warta Rimba 1(1): 1-8.

UPTD Tahura WAR. 2009. Buku Informasi Tahura. UPTD Tahura WAR, Bandar Lampung.

UPTD Tahura WAR. 2017. Blok Pengelolaan Taman Hutan Raya Wan Abdul Rachman. UPTD Tahura WAR, Bandar Lampung.

Yeates, G. W., Bongers, T., De Goede, R. G., Freckman, D. W., and Georgieva, S. S. 1993. Feeding habits in soil nematode families and genera-an outline for soil ecologists. Journal of nematology Society of Nematologists 25(3): 315-31. 